ORIGINAL ARTICLES

\title{
Production and purification of constructed recombinant hirudin in BL21(DE3) strain
}

\author{
Adnan I. Al-Badran ${ }^{1}$, Sabaa Ali Al-Fadal*2 \\ ${ }^{1}$ University of Basrah, College of Science, Biology department, Basra, Iraq \\ ${ }^{2}$ University of Basrah, College of Pharmacy, Pharmacognosay department, Basra, Iraq
}

Received: December 31, 2016

Accepted: February 22, $2017 \quad$ Online Published: March 1, 2017

DOI: $10.5430 /$ jbei.v3n1p62

URL: https://doi.org/10.5430/jbei.v3n1p62

\begin{abstract}
Background/Objective: Hirudin, an extract from the leech, has powerful antithrombin activity affecting the blood coagulation pathway, it is the most potent natural inhibitor of thrombin, it binds thrombin with high affinity, so, the aim of this study was to build hirudin gene by overlapping extension PCR then cloning and expression in BL21(DE3) strain.

Methods: Hirudin gene constructed with four modified primers then the final product amplified by two primers named as A, B by using overlapping extension PCR, for gene expression, BL21(DE3) strain was used under the control of T7 promoter in pET-16b vector and for hirudin production, LB broth medium was used as fermentation medium, to detect the expression of hirudin in BL21(DE3) strain in fermentation media real-time PCR was used. Hirudin protein purified at first by (Immobilized metal affinity chromatography) IMAC, then this protein was dialysis and treated with factor Xa to eliminate His-tag. Then hirudin purified by DEAE sepharose and SP sepharose column, the concentration of protein determined by ELISA, furthermore the activity evaluated by thrombin titration and activated partial thromboplastin time (APPT) test.

Results: Hirudin gene constructed in two round PCR first round produced two products (product 1,117 bp while product 2,114 bp) the second-round PCR gave the final product $213 \mathrm{bp}$. The resulted band from gel electrophoresis for constructed vector pET-16b-HirudinS was (5,901 bp). Hirudin expression was established by real-time PCR with Ct value (20.28). The analysis on $15 \%$ SDS-PAGE for the SP sepharose column illustrated the hirudinS protein band with size about $\sim 10.8$. Concentration of produced hirudin within its solution reached to $1.75 \mathrm{ng}$, thrombin titration method showed that the hirudin protein required $300 \mu \mathrm{l}$ from thrombin to clot, also, APPT test showed that hirudin elongated clotting time to $7 \mathrm{~min}$ in comparison with 6min for aspirin and the statistical analysis results for APPT test illustrated that there was no significant difference between hirudin and aspirin. Conclusion: This study approved that overlapping extension PCR is a good strategy for building hirudin gene and it's successfully expressed in BL21(DE3) strain.
\end{abstract}

Key Words: Overlapping extension PCR, APPT, ELISA, Hirudin, BL21(DE3) strain

\section{INTRODUCTION}

Overlap extension PCR represents a new approach to genetic engineering. It's not only allows for the analysis of the structural basis of gene and protein function, but also facilitates the generation of novel gene products. ${ }^{[1]}$ The method is pro- vided for joining two DNA molecules by first amplifying them by means of polymerase chain reactions (PCR) carried out on each molecule using oligonucleotide primers designed so that the ends of the resultant PCR products contain complementary sequences. When the two PCR products are

\footnotetext{
*Correspondence: Sabaa Ali Al-Fadal; Email: sabaaal.fadal@gmail.com; Address: University of Basrah, College of Pharmacy, Pharmacognosay department, Basra, Iraq.
} 
mixed, denatured and reannealed, the single-stranded DNA having the complementary sequences at their 3' ends anneal and then act as primers for each other. Extension of the annealed area by DNA polymerase produces a double-stranded DNA molecule in which the original molecules are spliced together. ${ }^{[2]}$ This method was used to produce hirudin gene. For example, in 2009 hirudin gene was produced by overlaping extension PCR and entering the gene in P. pastoris. ${ }^{[3]}$

Many medicinal proteins were produced by overlapping extension PCR one of these products is Hirudin which is a naturally occurring anticoagulant protein, isolated from the salivary glands of the medicinal leech it is the most potent known natural inhibitor of thrombin. Due to its high affinity for thrombin, hirudin inhibits almost all the physiological actions of thrombin. ${ }^{[4,5]}$ Hirudin reacts with thrombin in a 1:1 molar ratio to make a non-covalent complex whereby all biological effects of thrombin are blocked. The reaction of thrombin with hirudin is even more degraded than that between thrombin and its main physiological substrate, fibrinogen. ${ }^{[6]}$ The hirudin molecule has two distinct domains-an $\mathrm{NH} 2$ terminal core domin and a $\mathrm{COOH}$ terminal tail. The Nterminal binds and inhibits the active catalytic site of thrombin, whereas the carboxyl terminal simultaneously block the anion-binding exosite, many types of hirudin produced today by genetic engineering methods and also synthetically which differ in their structures and the way by which binding to the thrombin. ${ }^{[7,8]}$ For clinical use, hirudin has some potential advantage over other anticoagoulant drugs, in clinical studies with selected patients' populations, r-hirudin has been shown to be an effective and safe anticoagulant it works as a highly specific and selective thrombin inhibitor forming tight complex independent from cofactors like antithrombin. ${ }^{[9]}$ Thus, the aim of this study was to build hirudin gene by overlapping PCR and production it in BL21(DE3) strain.

\section{METHODS}

Building hirudin gene by overlapping extension PCR: Six primers were used to produce hirudin by overlapping $\mathrm{PCR}^{[3]}$ with modification which include elimination of Histag site from primers used in other studies because in this study we used vector $\mathrm{pET}-16 \mathrm{~b}$ which contain His-tag site also, elimination of Factor Xa part because the vector used contain Factor Xa site also. Primers (HS1, HS2, HS3, HS4) were designed for the combination of the DNA sequence of hirudin named as (HS) while primers A and B were designed to amplify (HS) gene and ligating it with pET-16b vector because it contains restriction site for restriction enzyme (NdeI on primers $\mathrm{A}, \mathrm{BamHI}$ on primers $\mathrm{B}$ ).

\section{HS1=5' GACCATATGGTTGTTTACACTGATTGCACCGAGTCTGGTCAAAACCTTTGCCTTTGCGAGGG TTCC-3'}

\section{HS2 $=5$ 'GTTCTTATCACCACGACCAAGAATGCACTTGTTACCTTGACCGCAAACGTTGGAACCCTCG CAAAG-3'}

\section{HS3=5'GGTCGTGGTGATAAGAACCAATGCGTTACTGGTGAAGGTACTCCTAAGCCTCAATCTCATA ACG-3' \\ HS4=5'GACGGATCCTTATTGAAGGTAATCCTCAGGAATTTCTTCGAAGTCACCATCGTTATGAGATT GAGG-3'}

\section{A=5'-GACCATATGGTTGTTTACACTGATTGCACC-3'}

\section{B =5'-GACGGATCCTTATTGAAGGTAATCCTCAGG-3'}

HS gene was produced by two round PCR by using PCR master mix (Promega, USA). The reaction mixture for first round PCR to produce product $1 \&$ product 2 was: $1 \mu \mathrm{HS} 1$ primer, $1 \mu \mathrm{l}$ HS2 primer, $12.5 \mu \mathrm{l}$ PCR master mix then the volume was completed to $25 \mu \mathrm{l}$ by nuclease-free water. $1 \mu \mathrm{l}$ HS3 primer, $1 \mu \mathrm{l} \mathrm{HS} 4$ primer, $12.5 \mu \mathrm{l}$ PCR master mix then the volume was completed to $25 \mu \mathrm{l}$ by nuclease-free water. While the reaction mixture for the second-round PCR to produce final product (HS gene) was: $20 \mathrm{ng}$ from product $1 \& 2$, $1 \mu \mathrm{l}$ primer A, $1 \mu \mathrm{l}$ Primer B, $12.5 \mu \mathrm{l}$ PCR master mix then the volume was completed to $25 \mu \mathrm{l}$ by nuclease-free water, and according to the conditions below. ${ }^{[3]}$ Initial denaturation at $94^{\circ} \mathrm{C}$ for $5 \mathrm{~min}$. followed by 35 cycle of denaturation at $94^{\circ} \mathrm{C} 30 \mathrm{sec}$, annealing at $55^{\circ} \mathrm{C} 30 \mathrm{sec}$, and extension at $72^{\circ} \mathrm{C} 30 \mathrm{sec}$. with final extension at $72^{\circ} \mathrm{C}$ for $10 \mathrm{~min}$. After first round PCR two products were produced [Product (1) $117 \mathrm{bp}$ and product (2) $114 \mathrm{bp}$ ], and the products were detected by $2 \%$ agarose gel. The PCR products were purified from gel by using MEGA quick-spinTM purification kit (Intron, USA) Catalog no. 17286. Purified products were used then to produced final product (HS gene) by using primers (A, B) to produced final product with $213 \mathrm{bp}$ which is also 
purified from the gel and send it to MACROGEN company http: //dna.macrogen. com for sequencing.

Cloning project: HS gene and plasmid pET-16b was digested with NdeI restriction enzyme (Biolab, U.K.) and BamHI (Promega, USA).

Ligation of (HS) gene and pET vector after digestion with restriction enzymes (NdeI, BamHI): The ligation reaction has been done according to ligation kit from (Bioneer, Korea) Catalog no. K-7103.

Transformation process: Transformation process has been done by inserted constructed plasmid pET-16b-HS into BL21(DE3) strain (Novagen, USA) Catalog no. 69450, then BL21(DE3) cells cultured on LB agar medium. Plasmid was extracted from transformed cells by using AccuPrep $\mathbb{R}$ Plasmid Mini Extraction Kit (Bioneer, Korea) Catalog no. K-3030 and analyzed by $0.8 \%$ agarose gel containing $1 \%$ ethidium bromide also HS gene was amplified from extracted plasmid by primers A\&B and analyzed by $2 \%$ agarose gel.

HS gene Expression in BL21(DE3): The protein expression and production in bacteria was carried out according to Novagen ${ }^{[10]}$ protocol and the Fermentation media: LB broth medium was also prepared according to Novagen. ${ }^{[10]}$

Detection of Hirudin Expression by real-time PCR: This process has been done by extraction of total RNA from BL21(DE3) strain from fermentation medium by using AccuZolTM reagent (Bioneer, Korea), the concentration of extracted RNA was determined according to. ${ }^{[11]}$ The GoScript ${ }^{\mathrm{TM}}$ Reverse Transcription System was used for the synthesis of cDNA from BL21(DE3) RNA. The

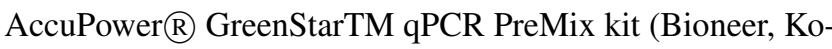
rea) Catalog no. k-6210 was used for real-time PCR reaction. Gene amplification in real-time PCR was performed in a final volume of $20 \mu \mathrm{l}$ of reaction mixtures contained $1 \mu \mathrm{l}$ A primer, $1 \mu \mathrm{l}$ B primer, $6 \mu \mathrm{l}$ cDNA, $10 \mu \mathrm{l}$ AccuPower $囚$ GreenStarTM qPCR PreMix (Bioneer, Korea) and $2 \mu$ l DEPEC-distilled water. The real-time PCR conditions were: $95^{\circ} \mathrm{C}$ for $10 \mathrm{~min}$, $95^{\circ} \mathrm{C}$ for $35 \mathrm{sec}, 55^{\circ} \mathrm{C}$ for $1 \mathrm{~min}$ and $72^{\circ} \mathrm{C}$ for $1 \mathrm{~min}$ for 45 cycles. Melting $62^{\circ} \mathrm{C}-96^{\circ} \mathrm{C}$ every $1 \mathrm{sec}$.

Preparation of cell lysis: This process has been done after cell preparation of cell lysate by using suspension buffer (100 mM Tris- $\mathrm{HCl}, 8 \mathrm{mM}$ Urea, $300 \mathrm{mM} \mathrm{NaCl}$, pH 7.5) with (0.1\% Lysosyme, $20 \mathrm{mM}$ PMSF and $\beta$-mercaptoethanol) then, incubated for $20 \mathrm{~min}$. at $37^{\circ} \mathrm{C}$. For homogenizing the sample, the sonication burst was given for $15 \mathrm{~min}$. at $4^{\circ} \mathrm{C}$ at $60 \mathrm{~Hz}$ intensity then centrifuged to remove unbroken cells debris.

\section{Purification by using HisLink ${ }^{\mathrm{TM}}$ Protein Purification}

Resin (Promega, USA) (immobilized metal affinity chromatography with modified): Because produced hirudin contain His-tag as a result for using pET-16b vector, therefore, using of IMAC is very effective, this process has been done by Loaded the supernatant from cell lysate onto column packed with $\mathrm{Ni}^{2+}$-chelating resin (Promega, USA) by using binding buffer (100 mM Tris-HCl, $8 \mathrm{mM}$ Urea, $300 \mathrm{mM}$ $\mathrm{NaCl}, 10 \mathrm{mM}$ imidazol, $\mathrm{pH}$ 7.5) and protein was eluted with buffer (100 mM Tris-HCl, $500 \mathrm{mM}$ imidazol, $\mathrm{pH}$ 7.5). The eluted protein collected and analyzed by $15 \%$ SDS-PAGE.

Dialysis: Protein produced after affinity chromatography was dialyzed with $10 \mathrm{X}$ solution $(100 \mathrm{mM}$ Tris- $\mathrm{HCl}, 100 \mathrm{mM}$ $\mathrm{NaCl}, 10 \%$ v/v glycerol, $0.1 \mathrm{mM}$ EDTA, $\mathrm{pH} 7.5$ for $4 \mathrm{~h}$ at $4^{\circ} \mathrm{C}$ and with $100 \mathrm{X}$ from the same solution for $16 \mathrm{~h}$ at $4^{\circ} \mathrm{C}$. ${ }^{[12]}$

Treatment with Factor Xa: To remove His-tag from produced protein, factor Xa (Biolab, U.K.) was used by incubation for $6 \mathrm{~h}$ at $23^{\circ} \mathrm{C}$ to obtain hirudin without His-tag.

Purification by DEAE Sepharose column (Anionexchange chromatography): $\mathrm{HiTrap}^{\mathrm{TM}}$ DEAE FF, $1 \mathrm{ml}$ column supplied by (GEHealthcare, Sweden) was used which equilibrated with $(20 \mathrm{mM}$ Tris- $\mathrm{HCl} \mathrm{pH}=8)$ then, hirudin eluted with [20 mM Tris- $\mathrm{HCl}$ with gradients of (0.1-0.5 M $\mathrm{NaCl}), \mathrm{pH} 8$ ]. The product analyzed by $15 \%$ SDS-PAGE.

Purification by SP Sepharose column (Cation-exchange Chromatography): HiTrap ${ }^{\mathrm{TM}}$ SP FF, $1 \mathrm{ml}$ column supplied by (GEHealthcare, Sweden) was used, the penetration collected from DEAE column and loaded to SP column which equilibrated with (Ammonium acetate $\mathrm{pH} 4.5$ ), washed with (Ammonium acetate $\mathrm{pH} 7$ ) then eluted (Ammonium acetate $\mathrm{pH} 8$ ). The product analyzed by $15 \%$ SDS-PAGE.

Hirudin Enzyme Immunoassay test: Human Hirudin ELISA Kit was used for the quantitative in vitro diagnostic measurement of hirudin in the solution by an enzyme immunoassay, according to the manufacture protocol (Mybiosource, USA) Catolog no. MBS262224.

Bioassay the activity of Hirudin (Hirudin Titration with Thrombin): The experiment has been done according to Markwardt ${ }^{[13]}$ by using $0.5 \%$ fibrinogen (Bioworld, USA) and (100 NIH unit/ml) thrombin solution (Sigma, USA).

Measurement of activated partial thromboplastin time (APPT) of Hirudin in comparison Acetyl-salicylic acid: The experiment has been done according to the protocol of the manufacture described in the BIO-CK APTT Kaolin kit (BIOLABO, France) Catalog no. 13560.

Statistical analysis: One way ANOVA was performed to evaluate results from (APPT) experiment using SPSS program (Statistical Package for Social Sciences) 19 software 
and $p \leq .05$ was considered statistically significant.

\section{RESUltS}

\section{Visualization of HS gene produced by overlapping PCR}

As shown in Figure 1, an illustration of the three products produced by two round PCR using $2 \%$ agarose gel containing ethidium bromide.

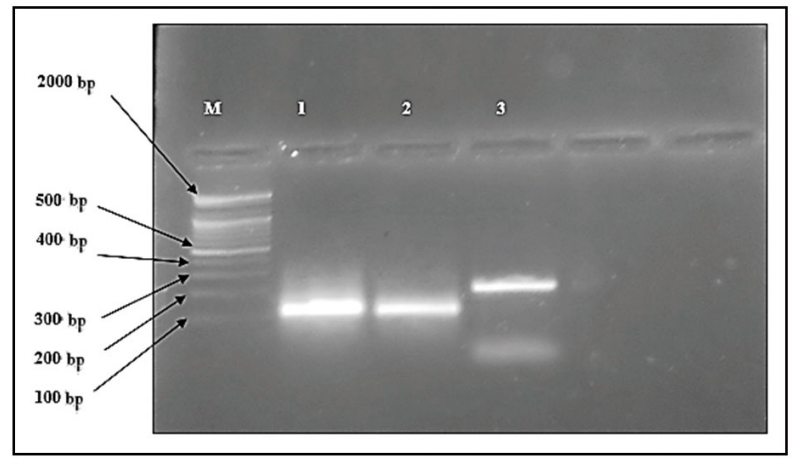

Figure 1. 2\% agarose gel analysis for products produced by two round PCR to synthesis HS gene. M: 100bp DNA ladder, lane 1: product 1 (117 bp), lane 2: product 2 (114 bp) and lane 3: HS gene (213 bp)

As shown in Figure 2, an illustration of HS gene after purification from gel using $2 \%$ agarose gel containing ethidium bromide, HS gene was successfully sequenced, aligned with BLAST, and approved this gene was hirudin.

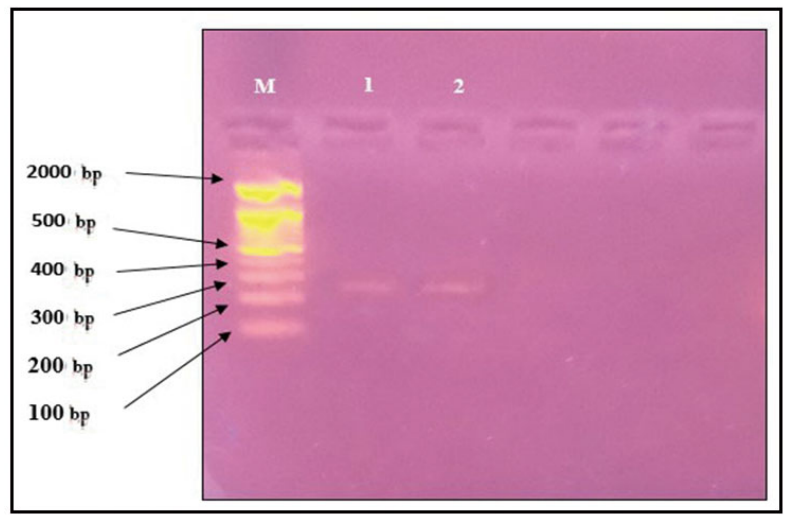

Figure 2. 2\% agarose gel analysis for HS gene purified from gel. M: 100 bp DNA ladder, Lanes 1, 2: HS gene 213 bp

As shown in Figure 3, BL21(DE3) strain was transformed with vector $\mathrm{pET}-16 \mathrm{~b}-\mathrm{HS}$.

Published by Sciedu Press

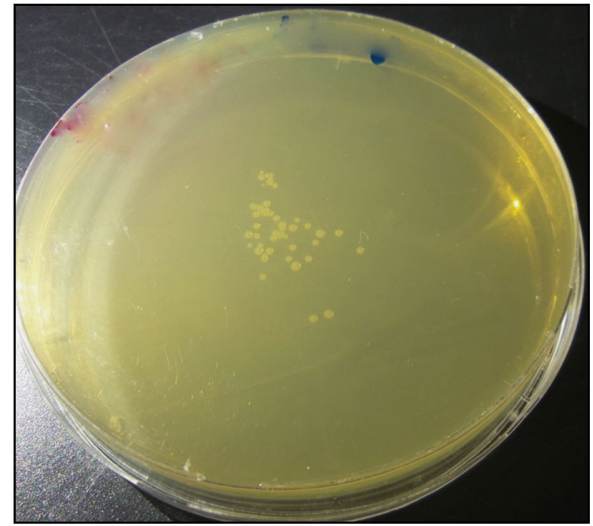

Figure 3. Transformed E. coli BL21(DE3)

\section{Screening by extraction pET-16-HS (constructive vec- tor)}

As shown in Figure 4, the band of constructive plasmid of about (5,901 bp) after extraction from competent cells, also Figure 5, show the band of target gene (HS) after amplification from the extracted constructive plasmid by (A, B primers).

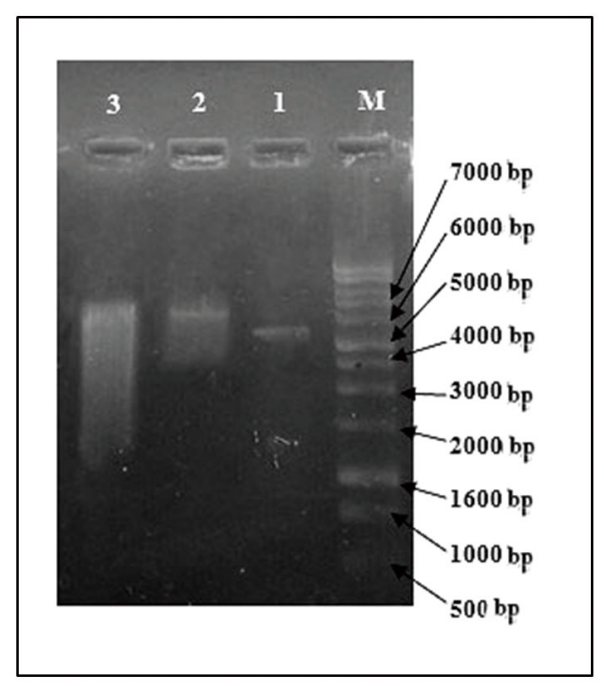

Figure 4. The analysis of $0.8 \%$ agarose gel electrophoresis for constructive pET-16b- HS extracted from competent cells. M: 500 bp DNA marker, lane 1: control with 5,711 bp and lane 2 and 3: constructive vector pET-16b-HS (5,901 bp)

\section{Hirudin (HS) Expression Detection by real - time PCR}

Hirudin expression was detected by real - time PCR, by extraction total RNA from BL21(DE3) strain harboring constructive vector pET-16b-HS with concentration $720 \mu \mathrm{g} / \mathrm{ml}$. then cDNA synthesized from total RNA for real-time PCR reaction, the results from Real time PCR illustrate in Figure 
6 which is threshold curve, $\mathrm{Ct}$ value for Hirudin gene was (20.28), melting curve illustrated in Figure 7.

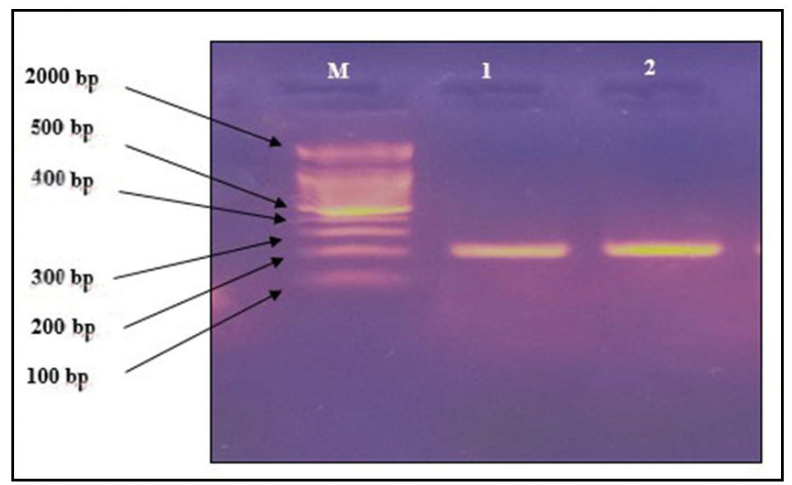

Figure 5. The analysis of $2 \%$ agarose gel electrophoresis for HS gene amplified from $\mathrm{pET}-16 \mathrm{~b}$ vector after extracted from competent cells. M: $100 \mathrm{bp}$ DNA marker, Lanes 1 and 2: HS gene $202 \mathrm{bp}$

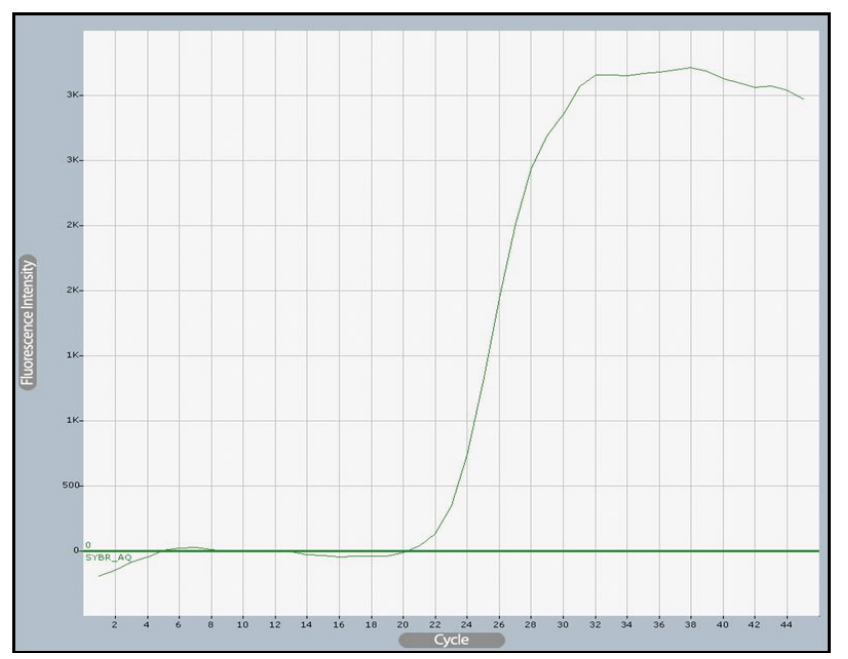

Figure 6. The Fluorescent Ct Curve for HS Gene

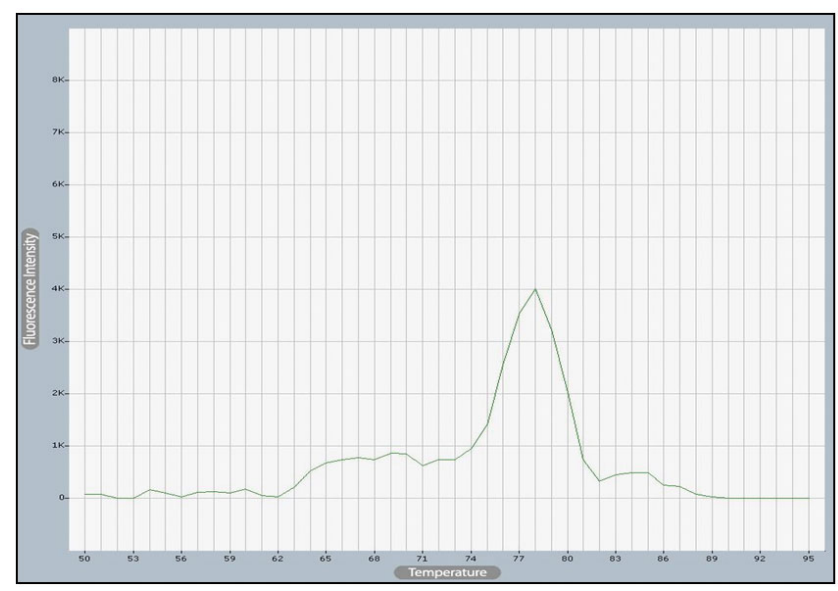

Figure 7. Melting Curve for HS Gene

\section{Purification by IMAC and DEAE Sepharose}

The presence of His-tag in the protein studied in this study lead to use IMAC technique, which make easy to elute his-tag protein in elution buffer but for more purification to reduce undesirable band, DEAE sepharose column was used after treatment with Factor Xa which lead to remove His-tag and reduced protein molecular weight to $\sim 10.83$ KDa. Samples collected from DEAE sepharose ion exchange chromatography detected the isolation of protein patterns, by the analysis of the result with $15 \%$ SDS-PAGE, hirudin give a sharp band on concentration of $\mathrm{NaCl}$ 0.2-0.4 M.

\section{Purification by SP sepharose}

As shown in Figure 8, the analysis on 15\% SDS-PAGE for the SP sepharose column shown the presence of hirudin protein in binding buffer $\mathrm{pH}=4.5$.

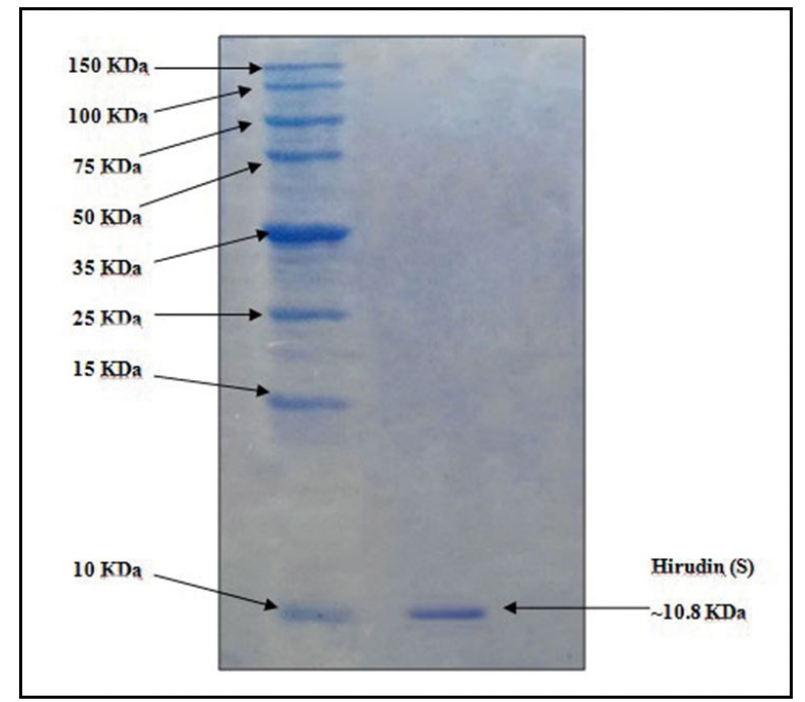

Figure 8. Coomassie blue stained SDS/polyacrylamide gel profile of protein from SP sepharose column for Hirudin $(\mathrm{S})$ protein. M: Marker protein $10 \mathrm{KDa}$. Lane 1: $\mathrm{pH}=4.5$ hirudinS band appear, Lane 2: $\mathrm{pH}=7$, Lane 3: $\mathrm{pH}=8$

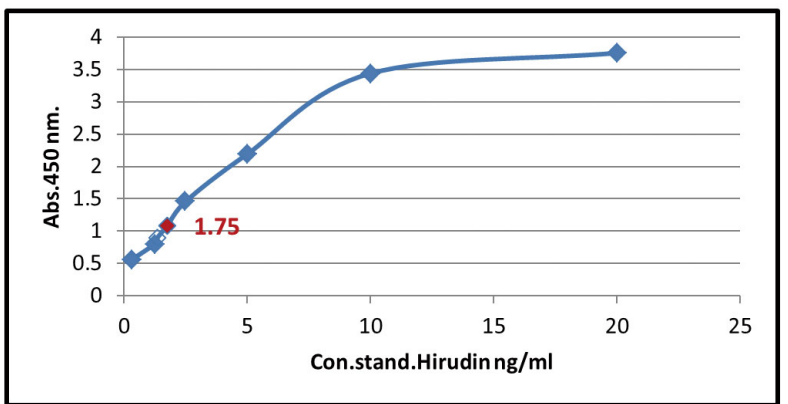


Figure 9. The standard curve with hirudin ELISA. The red square stands for $1.75 \mathrm{ng}$ hirudinS

\section{ELISA Immunoassay for hirudin}

As shown in Figure 9, the amount of hirudin in the solution was easy assayed by ELISA, by drawing standard curve, the concentration value as abscissa and OD value as vertical coordinate, the concentration determined which reached $1.75 \mathrm{ng}$.

\section{Detection of hirudin activity by titration with thrombin}

As shown in Table 1, the result for hirudin activity by thrombin titration method illustrated that $300 \mu$ l from thrombin required for clot formation in the presence of hirudin in comparison with controls.

Table 1. Thrombin volume for clot formation in thrombin titration with hirudin

\begin{tabular}{ll}
\hline & Thrombin titration volume/ $\mu l$ \\
\hline $\begin{array}{l}100 \mu \mathrm{l} \text { Hirudin } \mathrm{S}+200 \mu \mathrm{l} \\
\text { fibrinogen }\end{array}$ & $300 \mu \mathrm{l}$ \\
$\begin{array}{l}\text { Control1/ } 200 \mu \mathrm{l} \\
\text { fibrinogen }+100 \mu \mathrm{l} \text { water }\end{array}$ & $5 \mu \mathrm{l}$ \\
Control2/ $200 \mu \mathrm{l}$ fibrinogen & $5 \mu \mathrm{l}$ \\
\hline
\end{tabular}

\section{Activated partial thromboplastin time (APPT) of Hirudin in comparison with Acetyl-salicylic acid}

As shown in Table 2, it illustratse the elongation of clotting time to $7 \mathrm{~min}$. for hirudin in comparison with $6 \mathrm{~min}$ for acetyl salicylic acid.

Table 2. Activated partial thromboplastin time for hirudin in comparison with acetyl salicylic acid

\begin{tabular}{|c|c|c|}
\hline & & $\begin{array}{l}\text { Time for } \\
\text { clotting }\end{array}$ \\
\hline Control 1 & $\begin{array}{l}100 \mu \mathrm{l} \text { plasma } \\
100 \mu \mathrm{l} \text { BIO-CK reagent }\end{array}$ & $35 \mathrm{sec}$ \\
\hline Control 2 & $\begin{array}{l}100 \mu \mathrm{l} \text { plasma } \\
100 \mu \mathrm{l} \text { BIO-CK reagent } \\
100 \mu \mathrm{l} \text { Distilled water }\end{array}$ & $35 \mathrm{sec}$. \\
\hline Hirudin S & $\begin{array}{l}100 \mu \text { l plasma } \\
100 \mu \text { l BIO-CK reagent } \\
100 \mu \text { l Produced Hirudin }\end{array}$ & $7 \mathrm{~min}$. \\
\hline $\begin{array}{l}\text { Acetyl-salicylic } \\
\text { acid }\end{array}$ & $\begin{array}{l}100 \mu \mathrm{l} \text { plasma } \\
100 \mu \mathrm{l} \text { BIO-CK reagent } \\
100 \mu \text { l Acetyl-salicylic } \\
\text { acid }\end{array}$ & $6 \mathrm{~min}$. \\
\hline
\end{tabular}

Statistical analysis results illustrated there was a significant difference between (hirudin $\mathrm{S}$ ) and control, While the result was statistically insignificant between (hirudin $\mathrm{S}$ ) and Acetyl-salicylic acid.

\section{Discussion}

Extracting RNA is the first step in genetic engineering in case of eukaryotic gene transfer for gene expression in prokaryotic system, cloning process begins by obtaining RNA from eukaryotic source and then converted to cDNA by reverse transcriptase PCR kit and eventually transferred to prokaryotic system this process is not as easy as it looks but a complex and difficult process that goes for several reasons such as RNA is a much less stable molecule than DNA. Precautions must be taken to avoid contamination with RNAses, proteins, and genomic DNA, especially during RNA preparation and storage, while obtaining maximum yield. Poor RNA quality (including degradation and remaining impurities) can result in misleading results. Good quality RNA is important in modern molecular biological methods. ${ }^{[14,15]}$ Besides, dealing with a gene source like animal tissues as an example (leeches source of hirudin as in this study) requires a special treatment as immediate freezing of fresh tissue samples and the use liquid nitrogen. ${ }^{[16]}$ Because of that scientists tried to produce a gene without DNA or RNA extraction, especially if the gene in question is not large therefore the method known as overlap extension PCR was introduced. Overlapping PCR offer a new technique to build target gene without needing for RNA extraction, so, to save time and cost overlapping extension PCR was used in this study, it's an alternative method to generate linear expression fragments. During this study two PCR cycle was used to produce a final product (see Figure 1), overlapping PCR is a very flexible technique for producing gene, in this method a defined overlapping regions are added to the sequence of target gene during primers design, in first round PCR the reaction begin without primers which allows the overlapping regain to anneal together and extended by Taq polymerase to produce first products, in second round PCR the products from first round PCR mixed together to produced final product by overlapping region in the presence of Taq polymerase, The resulting full-length product finally is amplified by using a short pair of external primers, this DNA product can act directly as template for cloning and protein expression because of that overlapping PCR represent a rapid, simple method for gene cloning. ${ }^{[1,18]}$ For protein expression BL21(DE3) strain was used (see Figure 3), BL21(DE3) is one of the widely-used strain to check the basic protein expression in E. coli. Chromosomal DE3 prophase expresses T7 RNA polymerase under control of lac promoter also this strain lack Lon and OmpT proteases which will stabilize expression of some recombinant proteins, this strain form a compatible host for $\mathrm{pET}$ vector, constructive vector transferred to the host strain [BL21(DE3)], $\mathrm{pET}$ vector contain $\mathrm{T} 7$ promoter which is strong promoter produced their own RNA polymerase introduced into BL21(DE3) under the 
control of lac promoter, as long as T7 polymerase is a highly selective enzyme because of that when inserted plasmid with T7 promoter into strain without $\mathrm{T} 7$ polymerase the result is no expression, also $\mathrm{T} 7$ promoter is under the control of lac promoter. If IPTG is added to the culture, the lac promoter is derepressed T7 RNA polymerase is synthesized, and the gene is highly expressed, expression vectors usually contain a region of DNA, referred to as a transcriptional terminator downstream from the multiple cloning site where the cloned gene will be inserted. RNA polymerase reaching this site ceases transcription, so only the cloned gene itself will be transcribed from the strong promoter. ${ }^{[19,20]}$ Furthermore, BL21(DE3) strain also sensitive to the ampicillin while pET-16b vector carry ampicillin resistance as selective marker because of that the addition of ampicillin to the medium and the ability of BL21(DE3) strain grown on it due to harboaring pET-16b plasmid. ${ }^{[21]}$ In this study constructive vector pET-16b-HS was extracted (see Figure 4), and by electrophoresis with control the resulted band of constructive vector about 5,901 bp in comparison with control about 5,711 bp that's mean presence of target gene in constructive vector, for more detection from the constructive vector which extracted from transformed cell, Hirudin genes was amplifying with PCR cycle, the resulted band from gel electrophoresis about 202 bp (see Figure 5). To detect gene expression for Hirudin gene, real-time PCR has been done as the results shown in Figures $6 \& 7$, threshold curve. Threshold is a level of normalized reporter signal that is used for $\mathrm{Ct}$ determination in real-time assays. The level is set to be above the baseline but sufficiently low to be within the exponential growth region of an amplification curve. The cycle number at which the fluorescence signal associated with a particular amplicon accumulation crosses the threshold is referred to as the $\mathrm{Ct}$. $\mathrm{Ct}$ is threshold cycle, the cycle number at which the fluorescence generated within a reaction crosses the threshold line. Ct values are logarithmic and are used either directly or indirectly for the quantitative analyses. These $\mathrm{Ct}$ values are directly proportionate to the amount of starting template and are the basis for calculating mRNA expression levels or DNA copy number measurement. ${ }^{[22]}$

In spite of the importance of Ct curve but it depends on fluorescent signal emitting from binding SYBER GREEN dye to the dsDNA this simplicity means that they do not distinguish between different dsDNA products (example primer dimer) and it is important that PCR reactions be optimized for only the target amplicon is present, so other method employed to distinguish between different products which is (Melting point analysis). Melting point analysis is used to distinguish target amplicons from PCR artifacts such as primer-dimer, melting temperature (Tm) of each product is defined as the temperature at which the corresponding peak maximum occurs. This specificity of the chosen primers as well as reveal the presence of primer-dimers. Because of their small size primer-dimers usually melt at lower temperatures than the desired product. Additionally, non-specific amplification may result in PCR products that melt at temperature below or above that of desired product. A melting curve charts record the change in fluorescence observed when doublestranded DNA (dsDNA) with incorporated dye molecules dissociates, or "melts" into single-stranded DNA (ssDNA) as the temperature of the reaction is raised. When doublestranded DNA bound with SYBR green is heated a sudden decrease in fluorescence is detected when the melting point (Tm) is reached, due to dissociation of the DNA strands and subsequent release of the dye, so the fluorescence is plotted against temperature. Because the melting temperature of nucleic acids is affected by length, GC content, and the presence of base mismatches, among other factors, different PCR products can often be distinguished by their melting characteristics, the characterization of reaction products [e.g., prime-dimer Vs amplicon (product)] via melting curve analysis reduces the need for time-consuming gel electrophoresis, because other product may be appear in melting curve but in peaks are typically in a lower intensity and represent products that are shorter in length thus appear at a lower temperature than the target product because Tm is higher for long and in GC-rich PCR product. ${ }^{[23]}$

A widely-employed method utilizes immobilized metalaffinity chromatography (IMAC) to purify proteins containing a short affinity tag consisting of histidine residues (as in this study). IMAC is based on the interactions between a transition metal ion $\left(\mathrm{Co}^{2+}, \mathrm{Ni}^{2+}, \mathrm{Cu}^{2+}, \mathrm{Zn}^{2+}\right)$ immobilized on a matrix and specific amino acid side. Histidine is the amino acid that exhibits the strongest interaction with immobilized metal ion matrices, as electron donor groups on the histidine imidazole ring readily form coordination bonds with the immobilized transition metal. Peptides containing sequences of consecutive histidine residues are efficiently retained on IMAC column matrices. Following washing of the matrix material, peptides containing polyhistidine sequences can be easily eluted by either adjusting the $\mathrm{pH}$ of the column buffer or adding free imidazole to the column buffer. $^{[24]}$ In this study target protein contain 10-histidine and macroporous silica resin modified to contain a high level of tetradentate-chelated nickel was used for efficient capture and purification of bacterially expressed His-tag protein then target protein eluted by adding imidazole to the column buffer. ${ }^{[25]}$ Removal of the tag from a protein of interest can be accomplished with a site-specific protease and cleavage should not reduce protein activity. Factor Xa is protease was 
used in this study to cleave his-tag from target protein, this protease recognize a site between target protein and his-tag in N-terminal the recognition site consist from the flowing amino acid (Isoleucin - glutamic acid - glycin -Arginin), and cleaves after the carboxyl arginine. ${ }^{[26,27]}$ This treatment reduced the molecular weight of target protein by removing histag (molecular weight for Hirudin protein become $\sim 10.83$ $\mathrm{KDa}$ ). Then this protein purified by using DEAE sepharose (anion exchange chromatography). In DEAE sepharose target protein eluents by using salt $(\mathrm{NaCl})$, this salt is probably the most widely used and mild eluent for protein separation due to having no important effect on protein structure. ${ }^{[27]}$

In this study a linear salt gradients were used from (0.1-0.5 $\mathrm{M})$ in elution buffer the target protein band appear in concentration $(0.2-0.4 \mathrm{M}),{ }^{[28]}$ by using Tris- $\mathrm{HCl}$ buffer with $\mathrm{pH}$ $=8(20 \mathrm{mM})$ in binding and washing buffer without $\mathrm{NaCl}$ then elute protein with gradient $\mathrm{NaCl}$ allowing counterion $\mathrm{Cl}$ to bind to the DEAE exchanger and elute target protein. SP sepharose is cation exchanger with negatively charge functional group, target protein eluent from this column depending on iso-electric point (PI) which is the $\mathrm{pH}$ at which the net charge of the protein is neutral (the number of positive charges is equal to the number of negative charges). The result for SP sepharose was illustrated in Figure 8, Hirudin protein eluted in buffer $(\mathrm{pH}=4.5){ }^{[29]}$

The biological activity of hirudin conducted by thrombin titration. Titration is an analytical technique which allows the quantitative determination of a specific substance (analyte) dissolved in a sample. It is based on a complete chemical reaction between the analyte and a reagent (titrant) of known concentration which is added to the sample. During this experiment a specific, rapid, and stoichiometric reaction between hirudin and thrombin, hirudin activity can be quanti- tatively determined by titration with a standardized thrombin solution. The principle involved a fibrinogen solution to which hirudin was added will not clot until enough thrombin is added to neutralize all of the hirudin present (see Table $1),{ }^{[13,30]}$ the results from APPT test illustrate long clotting time about $7 \mathrm{~min}$. for (hirudin S) (see Table 2), because the specificity of hirudin to directly target bound thrombin and not as other anticoagulant drug with multiple sites of action as heparin and vitamin $\mathrm{K}$ antagonist. ${ }^{[31]}$

Statistical analysis illustrates there is no significant difference between aspirin which is a famous anticoagulant drug widely used for cardiovascular disease and (hirudin S), the increasing number of people being exposed to aspirin has also led to the awareness of the significant potential harm arising from the adverse haemorrhagic effects of aspirin such as gastrointestinal and intracranial bleeds. Hence there needs more investigation to assess the therapeutic indications of aspirin and decide whether anticipated benefit outweighs the potential of harm for example patients with high risk of vascular disease antiplatelet therapy has been shown to reduce vascular events by about a quarter, in this case aspirin treatment benefit seem to outweigh the risk but also aspirin is known to cause GI tract erosion resulting in occult bleeding specially for people with stomach ulcer in contrast hirudin is a newer and more specific drug directly binding to the thrombin. ${ }^{[31,32]}$ Hirudin also administrated by intravenous injection that means without effect on stomach and excreted by kidney because of that we can consider hirudin as a good alternative drug for people suffering from side effect as a result from using aspirin and other anticoagulant drugs. ${ }^{[4]}$

\section{ACKNOWLEDGements}

The authors are grateful to the laboratory of Cell and Biotechnology Researches Unit.

\section{REFERENCES}

[1] Ho SN, Hunt HD, Horton RM, et al. Site-directed mutagenesis by overlap extension using the polymerase chain reaction. Gene. 1989; 77: 51-59. https://doi.org/10.1016/0378-1119(89) 90358 $-2$

[2] Ho SN, Horton RM. Method for gene splicing by overlap extension using the polymerase chain reaction. United States Patent. 1992; 19: $1-4$.

[3] Hu Z, Zhang M, Gu F, et al. Expression, purification and characterization of recombinant targeting bifunctional hirudin in Pichia pastoris. African Journal of Biotechnology. 2009; 8(20): 5582-5588.

[4] Greinacher A, Warkentin TE. The direct thrombin inhibitor hirudin. Thrombosis and Haemostasis. 1989; 99(5): 819-829.

[5] Abbas zaidi SM, Jameel SS, Zaman F, et al. A systematic Overview of the Medicinal Importance of Sanguivorous Leeches. Alternative
Medicine Review. 2011; 16(1): 59-65.

[6] Bichler J, Fritz H. Hirudin, a new therapeutic tool? Annals of Hematology. 1991; 63(2): 67-76. Available from: www.ncbi.nlm.nih.g ov/pubmed/1912033

[7] Otto A, Seckler R. Characterization, stability and refolding of recombinant hirudin. European Journal Biochemistry. 1991; 202: 67-73. https://doi.org/10.1111/j.1432-1033.1991.tb16345.x

[8] Lefkovit J, Topol EJ. Direct Thrombin Inhibitors in Cardiovascular Medicine. Circulation. 1994; 90: 1522-1536. https://doi.org/ 10.1161/01.CIR.90.3.1522

[9] Frank R, Farber H, Stefanidis I. Hirudin elimination by hemofiltration: a comparative in vitro study of different membranes. Kidney International. Supplement. 1999; 56(72): 41-5.

[10] Novagen. Competent cells user manual. Novagen Catalog; 2011 p1-19. 
[11] Sambrook J, Frtish E, Maniatis T. Molecular cloning, a Laboratory Mannual. 2nd ed. Gold Spring Harbor Laboratory Press. USA; 1989

[12] Santos CA, Beloti LL, Toledo MA, et al. A novel protein refolding protocol for the solubilization and purification of recombinant peptidoglycan-associated lipoprotein from Xylella fastidiosa overexpressed in Escherichia coli. Protein Expression and Purification. 2012; 82: 284-289. PMid:22306742. https://doi.org/10.101 $6 / j \cdot$ pep. 2012.01.010

[13] Markwardt F. Hirudin as an Inhibitor of Thrombin. Method Enzymolog. 1970; 69: 924-932. https://doi.org/10.1016/0076-6 879 (70) 19082-3

[14] Zakaria Z, Umi SH, Mokhtar SS, et al. An alternate method for DNA and RNA extraction from clotted blood. Genetics and Molecular Research. 2013; 12(1): 302-311. PMid:23408417. https : //doi.org/10.4238/2013.February.4.4

[15] Cirera S. Highly efficient method for isolation of total RNA from adipose tissue. Biomedical Centeral Research Notes. 2013; 6: 472 Available from: http://www.ncbi.nlm.nih.gov/pubmed/2424 5791

[16] Samadani AA, Nikbahksh N, Fattahi Pourbagher R, et al. RNA Extraction from Animal and Human's Cancerous Tissues: Does Tissue Matter? International Journal Molecular Cellular Medicine. 2015; 4(1): 1-6.

[17] Roche. Generation of linear expression elements by PCR. Roche Applied Science. 2002: 1-6.

[18] Gibson DG. Enzymatic assembly of overlapping DNA fragments. Methods in Enzymology. 2011; 498: 349-361. PMid:21601685. https://doi.org/10.1016/B978-0-12-385120-8.00015-2

[19] Joseph BC, Pichiamuthu S, Srimeenakshi S, et al. An overview of the parameters for recombinant protein expression in Escherichia coli. Cell Science and Therapy. 2015; 6(5): 1-7.

[20] Padmanabhan S, Banerjee S, Mandi N. Screening of Bacterial recombinants: strategies and preventing false positive. Molecular Cloning - Selected Applications in Medicine and Biology. 2011 p1-19. Avaliable from: http://www.intechopen.com/books /molecular-cloning-selected-applications-in-medic ine-and-biology/screening-of-bacterial-recombinant s-strategies-and-preventing-false-positives
[21] Bornhorst JA, Falke JJ. Purification of proteins using polyhistidine affinity tags. Methods in Enzymology. 2000; (326): 245-254.

[22] Ma H, Shich K, Qiao X, et al. Application of Real-time polymerase chain reaction (RT-PCR). Journal of American Science. 2006; 2(3): $1-15$.

[23] Marina B, Tan L, Park R, et al. Identification of Non specific product using melt-curve analysis on the iCycler iQTm detection system. Bio-rad Labrotories.

[24] Promega. HisLink ${ }^{\mathrm{TM}}$ Protein Purification Resin. Promeg Catalog. Promega corporatio. 2013. p1-17.

[25] Terpe K. Overview of tag protein fusions: from molecular and biochemical fundamentals to commercial systems. Applied Microbiology Biotechnology. 2003; 60: 523-533. PMid:12536251. https://doi.org/10.1007/s00253-002-1158-6

[26] Young CL, Britton ZT, Robinson AS. Recombinant protein expression and purification: A comprehensive review of affinity tags and microbial applications. Biotechnology Journal. 2012; 7: 620-634. PMid:22442034. https ://doi .org/10.1002/biot. 201100155

[27] Acikara ÖB. Ion exchange chromatography and its applications. Column chromatography. 2013: 31-58.

[28] Jun WL, Jun L, Bin W, et al. Optimization for purification and charicterization of recombinant Hirudin III from E. coli. Chinese Pharmaceutical Sciences. 2005; 14(2): 79-85.

[29] GE Healthcare. Ion exchange columns and media. selection guide. 2008. p1-8.

[30] Chen HY, Zhang JH, LU J, et al. Simple and efficient methods for isolation and activity measurement of the recombinant hirudin variant 3 from Bacillus subtilis. African Journal of Biotechnology. 2011; 10(44): 8889-8894.

[31] Walker CPR, Royston D. Thrombin generation and its inhibition: A review of the scientific basis and mechanism of action of anticoagulant therapies. British Journal of Anaesthesia. 2002; 88: 848-863. https://doi.org/10.1093/bja/88.6.848

[32] Kwok C, Loke Y. Critical overview on the benefits and harms of aspirin. Pharmaceuticals. 2010; 3(5): 1491-1506. PMid:27713314. https://doi .org/10.3390/ph3051491 